\title{
Benefits not appreciated
}

DESPITE the promise of nuclear energy in the avoidance of global warming, $1990 \mathrm{did}$ little to resolve the continuing argument about the prudence of building nuclear plants. And the chances are that 1991 will leave most matters unresolved.

Yet the debate has at least begun. In Sweden, for example, the earlier decision that nuclear power would be phased out when existing nuclear plants reach the ends of their lives has been questioned (mostly by industrialists concerned to know where alternative energy sources would be found). The argument is likely to become lively before it is settled.

In the United States, a similar debate also began in earnest, mostly centred about the potential of new reactor designs. It might have been more constructive if it had not been consistently overshadowed by reports of environmental contamination at US nuclear weapons production facilities.

There were, for example, new fears of chemical explosions in the underground tanks holding high-level nuclear waste at the Hanford reservation. There was little progress during 1990 at the Yucca Mountain site earmarked for the disposal of high-level commercial waste, or at many of the sites designated for low-level waste which are required by law to be in operation by 1993 .

Some vestigial controversies have nevertheless been resolved. The Environmental Protection Agency in 1990 finally approved a testing period for the salt-bed repository in New Mexico intended for military transuranic waste. And the long-contested Seabrook nuclear power plant in New Hampshire finally won its operating license.

Other long-standing controversies have been revived in the United States. During 1990 , interest in the health threat posed by low levels of radiation was confused by conflicting results from research. A study completed this year by the National Cancer Institute found no increased incidence of cancer among neighbours of selected nuclear reactors across the United States, but there is epidemiological evidence of elevated leukaemia rates among those living near the Pilgrim power plant in Massachusetts.

In Japan, despite public opposition to nuclear power since the Chernobyl accident, the Japanese government seeems determined to carry on with its ambitious plans to expand nuclear power. But the government will face a political test of its policy in February, when an anti-nuclear power candidate will be among those running for the post of governor in Aomori Prefecture on the northern tip of the main island of Japan, where a huge complex for reprocessing and enriching nuclear fuel and for storing low-level and and highlevel waste is being built.

The complex has become a focus of a nationwide campaign by anti-nuclear activists. Although many living in the immediate vicinity of the complex have been mollified by the government's generous grants for new local facilities, many farmers and fishermen nearby are still opposed to the plant, fearing that sales of their products will be reduced.

Meanwhile, Europe's top nuclear nation continues to test missiles and their warheads in the South Pacific (and caesium-134 has been found in the surrounding sea). At home, although the nuclear industry gives France a good record on carbon dioxide emissions, the security of its reactor plants and waste treatment installations has been questioned by a string of minor, but potentially serious, oversights.

In Britain, the nuclear industry must be glad to see the back of 1990. The government's ill-conceived and subsequently aborted plan to sell British nuclear power stations to private investors was attacked in a damning report from the House of Commons Energy Committee, which did much to uncover the mystery of how the costs of nuclear-generated electricity spiralled in the run-up to privatization. The new government-owned nuclear generating companies face another year of stagnation, with Britain's nuclear programme on hold, pending a review in 1994.

The UK Atomic Energy Authority, now trading as AEA Technology, lost money, closed research reactors and shed staff in 1990, and is placing its hopes on diversification away from the nuclear industry.

Perhaps the biggest blow came in February, when a controversial study by a team led by Martin Gardner, from the University of Southampton, linked the excess of childhood leukaemia cases around British Nuclear Fuels Limited's (BNFL)'s Sellafield waste reprocessing plant to their fathers' exposure to radiation at the plant. BNFL will take some comfort from the subsequent failure to find excess cancer cases around nuclear sites in the United States and France.

The deepest confusion on nuclear power is in Eastern Europe. What looked at first like a wide-open market for Western nuclear plant constructors is proving to be a tough sell.

Germany, which abandoned domestic reprocessing of nuclear fuel in 1989 , made no move last year to build new nuclear plants in its eastern regions. Instead, the five Soviet-built plants, which used to provide more than 10 per cent of East Germany's electricity, have been shut and replaced in stopgap fashion with gas-fired and oil-fired plants from the west. Despite Germany's intention to reduce both carbon dioxide emissions and dependence on foreign oil, the plants are likely to remain in place. Building new nuclear plants is just too unpopular.

Hungary and Czechoslovakia are in a similar position. They have so far resisted proposals from the West that they should provide sites for modern nuclear plants that would be paid for by deliveries of electricity to the West.

The decision in mid-1990 to close the Soviet-designed plants at Greifswald, Germany, followed a Western safety study that revealed fundamental design and maintenance flaws. The same flaws would surely be found at identical plants in Czechoslovakia, Bulgaria and the Soviet Union, none of which can afford to shut them down. Indeed, the plant at Kozloduy accounts for more than 40 per cent of Bulgaria's electrical generating capacity. A negative outcome of the safety study now being conducted by the International Atomic Energy Agency and due to be completed this year could throw Bulgaria into an energy crisis.

In Germany proper, the defeat of the Green Party in the December Bundestag elections by no means signals the end of the antinuclear movement. The first battle of 1991 will come over the perennial nuclear waste problem; the dump sites selected by both East and West Germany are considered inappropriate by nuclear opponents and are viewed just as critically by the government of Lower Saxony, in which the Greens are a junior partner.

There is also a potential nuclear scandal brewing over the former Soviet uranium mining areas near Aue in Saxony and Gera in Thuringia. How badly was the local population contaminated? No one knows, but there are plenty of people anxious to find out.

\section{ANTARCTICA}

\section{A deep depression}

LAST year was a disappointment for many Antarctic researchers, who know that 1991 may be no better. The 39 Antarctic Treaty nations, at a three-week meeting in Chile that finished last month, made a start on a new protocol to protect the Antarctic environment.

But much remains to be done, starting at a meeting in Madrid in April, where the divisive issue of future minerals exploitation in Antarctica will be raised.

Japan, Britain and the US would like to keep open the option for future mining, but other nations, led by Australia and France, want a permanent ban. Some Antarctic scientists are concerned that a new regime for environmental protection in Antarctica may restrict research. 